\title{
A convenient method for the synthesis of 3,6-dihydroxy- benzene-1,2,4,5-tetracarboxylic acid tetraalkyl esters and a study of their fluorescence properties
}

\author{
Aswathy L. Balachandran, Vidya Sathi, Ani Deepthi,* and Chettiyam V. Suneesh \\ Department of Chemistry, University of Kerala, Thiruvananthapuram 695581, Kerala, India \\ E-mail: anideepthi@gmail.com
}

DOI: http://dx.doi.org/10.3998/ark.5550190.p009.843

\begin{abstract}
A mild, efficient and simple method for the synthesis of 3,6-dihydroxy-1,2,4,5-tetracarboxylic tetraalkyl esters using cerium(IV) ammonium nitrate mediated oxidation of 1,3-acetone dicarboxylates has been developed. The detailed absorption and emission studies of the synthesized compounds reveal that these molecules have appreciable quantum yields and possess large Stokes shift values.
\end{abstract}

Keywords: Pyromellitic dianhydride, 1,3,5-tricarbonyl compounds, cerium(IV) ammonium nitrate, quantum yield, Stokes shift

\section{Introduction}

Among other methods, ${ }^{1}$ vapour phase oxidation of pyromellitic acid leads to the synthesis of pyromellitic dianhydride (PMDA) which in-turn is the chief raw material for the production of polyimides $^{2}$ that are used in aircraft industry and cryogenics. ${ }^{3}$ Apart from the production of PMDA, pyromellitic acid has also been extensively used for the synthesis of Metal Organic Frameworks $(\mathrm{MOFs})^{4}$ which has rich applications in gas storage, catalysis, luminescent sensing and separations. ${ }^{5}$ Conventional synthesis of pyromellitic acid from $p$-xylene involves an initial chloromethylation followed by oxidation of the resulting compound using organometallic catalysts. ${ }^{6-9}$ Modified methods for its synthesis using ionic liquids have also been reported. ${ }^{10}$ However, to the best of our knowledge, except for a few isolated early reports, ${ }^{11,12}$ further studies on pyromellitic acid derivatives with hydroxyl substituents in the 3,6-positions are unknown in the literature. In the aforementioned reports, von Pechmann and Hammond have used sodium wire and iodine for the synthesis of these compounds (Scheme 1). The method is both cumbersome and very low yielding. At the same time, 3,6-dihydroxybenzene-1,2,4,5-tetracarboxylates are the only direct source of 1,4-benzoquinone-2,3,5,6-tetracarboxylates which are strong electron-acceptors. ${ }^{12}$ Hydroquinone/quinone redox couples are the widely used electron transport cofactors in the 
natural photosynthetic reaction centres. ${ }^{13}$ Recently, hydroquinones are also finding application as electron relays in artificial photosynthesis. Several hydroquinones are tested as electron shuttles in the photocatalytic system, employed for the reduction of water to molecular hydrogen. ${ }^{14}$ Hence it is highly desirable to develop a simple, mild and more efficient method for the synthesis of the abovementioned hydroquinone molecules. Herein, we present a mild and less toxic synthesis of 3,6-dihydroxybenzene-1,2,4,5-tetracarboxylic acid tetraalkyl esters by oxidative dimerization of 1,3-acetone dicarboxylates using cerium(IV) ammonium nitrate (CAN). ${ }^{15,16}$ The preliminary photophysical studies of these compounds are also included.

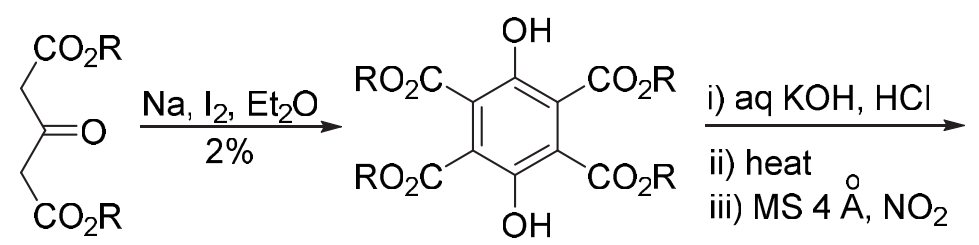<smiles>O=c1oc(=O)c2c(=O)c3c(=O)oc(=O)c3c(=O)c12</smiles>

Scheme 1. Reported method ${ }^{12}$ for the synthesis of 3,6-dihydroxybenzene-1,2,4,5-tetraalkylcarboxylates and 1,4-cyclohexadiene-1,2,4,5-tetracarboxylic acid 1,2,4,5-dianhydride.

1,3,5-Tricarbonyl compounds constitute an important reactive class of active methylene compounds reported to participate in a variety of reactions. ${ }^{17-20}$ Hayashi et. al.,${ }^{21}$ have shown that these compounds can undergo Michael-Knoevenagel reaction with $\alpha, \beta$-unsaturated ketones to yield cyclohexenones stereoselectively. More recently, studies have also proved that they can undergo coupling reaction with bromo acetophenones to produce cyclopentenones. ${ }^{22}$ Previous work in our group has shown that 1,3-dicarbonyl compounds can be converted to 1,2,3-tricarbonyl compounds in a facile manner using $10 \mathrm{~mol} \%$ of CAN. ${ }^{23}$ The latter observation prompted us to investigate the reaction of dialkyl-1,3-acetone dicarboxylates towards CAN and the details are presented below.

\section{Results and Discussion}

As a pilot experiment, dimethyl 1,3-acetone dicarboxylate 1a was treated with $30 \mathrm{~mol} \% \mathrm{CAN}$ in dry acetonitrile as solvent. The reaction was monitored by TLC and majority of the starting material was consumed within 12 hours. Work-up followed by column chromatography afforded a new compound $\mathbf{2 a}$ in $41 \%$ yield (67\% yield based on recovered dimethyl 1,3-acetone dicarboxylate 1a) (Scheme-2). 
<smiles>[R]OC(=O)CC(=O)CC([R])=O</smiles>

$1 a$<smiles>[R]OC(=O)c1c(O)c(C(=O)O[R])c(C([R])=O)c(O)c1C([R])=O</smiles>

\section{$2 a$}

(i) CAN (30 mol\%), dry $\mathrm{CH}_{3} \mathrm{CN}$, ice - $\mathrm{RT}, 12 \mathrm{~h}, 41 \%(67 \%)$

Scheme 2. The CAN mediated reaction.

The structure of product 2a was established by spectroscopic analysis. In the IR spectrum of 2a the appearance of a broad absorption peak at $3024 \mathrm{~cm}^{-1}$ indicated the presence of intramolecularly hydrogen bonded $\mathrm{OH}$ groups, while ester carbonyl groups showed stretching frequency at $1736 \mathrm{~cm}^{-1}$. In the ${ }^{1} \mathrm{H}$ NMR spectrum, $\mathrm{OH}$ proton was seen at $\delta_{\mathrm{H}} 10.54 \mathrm{ppm}$ as a singlet and methoxy protons were observed at $\delta_{\mathrm{H}} 3.95 \mathrm{ppm}$. In the ${ }^{13} \mathrm{C}$ NMR spectrum, ester carbonyl carbon appeared at $\delta_{\mathrm{C}} 166.8 \mathrm{ppm}$ and the two aromatic carbons were seen at $\delta_{\mathrm{C}} 149.9$ and 120.2 ppm respectively. Methoxy carbon was observed at $\delta_{\mathrm{C}} 53.2 \mathrm{ppm}$. The mass spectrum also agreed with the proposed structure of $\mathbf{2 a}$. The compound was thus characterized as 3,6-dihydroxybenzene1,2,4,5-tetracarboxylic acid tetramethyl ester.

Subsequently, the generality of the reaction was studied using various 1,3-acetone dicarboxylate esters $\mathbf{1 b}$-i. The latter compounds were synthesized using the classical Steglich esterification of 1,3-acetone dicarboxylic acid with corresponding alcohols. ${ }^{24}$ The synthesized compounds were treated with $30 \mathrm{~mol} \% \mathrm{CAN}$ to yield the corresponding 3,6-dihydroxybenzene1,2,4,5-tetracarboxylic acid tetraalkyl esters $\mathbf{2} \mathbf{b}-\mathbf{i}$ in moderate yields (Table 1, entries 1-8). Usage of higher amounts of CAN led to the formation of additional products possibly due to the cleavage of starting compounds. All compounds were characterized using the usual spectroscopic techniques.

Table 1. Generality of the reaction

\begin{tabular}{cccc}
\hline Entry & $\mathrm{R}$ & Product & Yield (\%) \\
\hline 1 & $\mathrm{Et}$ & $\mathbf{2 b}$ & $45(54)^{a}$ \\
2 & $n-\mathrm{Pr}$ & $\mathbf{2 c}$ & $45(60)^{a}$ \\
3 & $n$-Bu & $\mathbf{2 d}$ & $47(59)^{a}$ \\
4 & $n$-pentyl & $\mathbf{2 e}$ & $43(51)^{a}$ \\
5 & $i$-Pr & $\mathbf{2 f}$ & $48(61)^{a}$ \\
6 & $t$-Bu & $\mathbf{2 g}$ & $47(60)^{a}$ \\
7 & $c-\mathrm{Hex}$ & $\mathbf{2 h}$ & $45(51)^{a}$ \\
8 & $\mathrm{Bn}$ & $\mathbf{2 i}$ & $43(53)^{a}$ \\
\hline
\end{tabular}

${ }^{a}$ Product yield based on recovered starting material in parenthesis. 
Encouraged by the results obtained by using dialkyl acetone 1,3-dicarboxylates, we then tried the reaction of 1,5-diphenylpentane-1,3,5-trione (3) with CAN. Under identical reaction conditions, we observed the formation of a product 4 in $42 \%$ yield (61\% based on recovered 3 ) which was isolated and purified by column chromatography (Scheme 3 ).

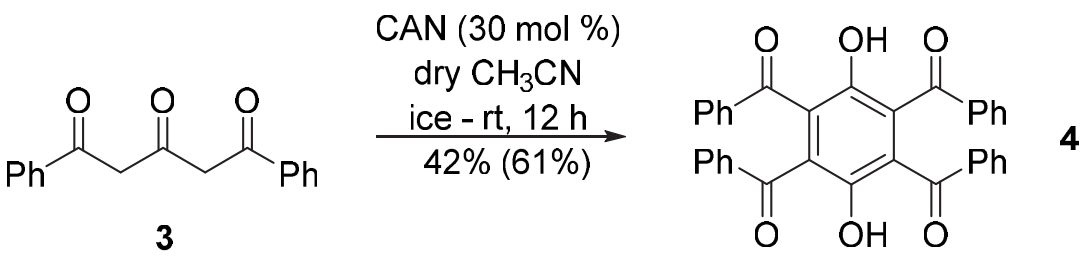

Scheme 3. Reaction of 1,5-diphenylpentane-1,3,5-trione (3) with CAN.

Spectroscopic analysis established the structure of the product 4 . The appearance of a broad absorption peak in the IR spectrum of 4 at $3071 \mathrm{~cm}^{-1}$ indicate the presence of intramolecularly hydrogen bonded $\mathrm{OH}$ groups at the $\mathrm{C}-3$ and C- 6 positions of the benzene ring, while benzoyl carbonyl groups showed stretching frequency at $1684 \mathrm{~cm}^{-1}$. In the ${ }^{1} \mathrm{H}$ NMR spectrum, the $\mathrm{OH}$ proton were seen at $\delta_{\mathrm{H}} 10.08 \mathrm{ppm}$ as a singlet. The aromatic protons were observed at $\delta_{\mathrm{H}} 7.1-8.0$ ppm. In the ${ }^{13} \mathrm{C}$ NMR spectrum, the benzoyl carbonyl carbon appeared at $\delta_{\mathrm{C}} 194.7 \mathrm{ppm}$ and the aromatic carbons of the hydroxyl appended benzene ring were seen at $\delta_{\mathrm{C}} 126.8$ and $148.9 \mathrm{ppm}$. The $[\mathrm{M}+\mathrm{Na}]$ peak was observed at 549.5345 in the mass spectrum of 4 . The compound was thus characterized to be 3,6-dihydroxy-1,2,4,5-tetrabenzoylbenzene. The synthesis of other heteroalkoxy and alkoxy hydroquinones and their oxidation to the corresponding quinones are underway in our laboratory.

Mechanistically, the reaction probably takes place by the initial formation of the radical cation I. Subsequently two molecules of I dimerize to form II. During this process, 4 moles of Ce(IV) are converted to Ce(III). Enolization of II yields III which undergoes a secondary oxidation to form the final product 2 . The re-oxidation of $\mathrm{Ce}$ (III) to $\mathrm{Ce}(\mathrm{IV})$ takes place probably due to the interference of oxygen present in the reaction atmosphere. Control experiments done in the presence of nitrogen resulted in a drastic decrease in the yield of the product substantiating our air oxidation mechanism. At the same time, when the reaction was carried out by purging air through the reaction mixture, the radical cation intermediate evidently was quenched leading to a low yield of product. The desired product $\mathbf{2}$ was formed only in moderate yield since during the course of the reaction small amounts of unidentified cleavage side-products were produced, the amount of which increased when the mol \% of CAN was increased. After repeated experiments by varying the amount of CAN, $30 \mathrm{~mol} \%$ was found to be the optimal amount required for the formation of the desired product $\mathbf{2}$ in moderate yields. The mechanistic details are presented in the scheme below. 


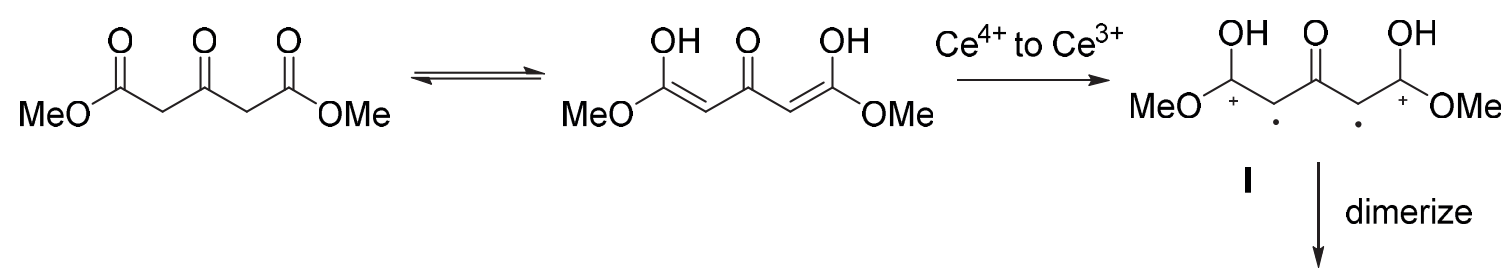<smiles>COC(=O)c1c(O)c(C(=O)OC)c(C(=O)OC)c(C(=O)OC)c1O</smiles><smiles>COC(=O)C1=C(O)C(C(=O)OC)C(C(=O)OC)=C(O)C1C(=O)OC</smiles>

III<smiles>COC(=O)C1C(=O)C(C(=O)OC)C(C(=O)OC)C(=O)C1C(=O)OC</smiles>

II

Scheme 4. Proposed reaction mechanism.

The synthesized compounds exhibited fluorescence behavior upon excitation with UV light of wavelength $366 \mathrm{~nm}$ which prompted us to carry out a detailed absorption and emission study. Figure 2 shows the absorption and fluorescence spectra of a representative compound, $\mathbf{2 b}$ in acetonitrile. The long wavelength absorption exhibited maximum at $377 \mathrm{~nm}$ with an extinction coefficient, $\varepsilon 374 \mathrm{M}^{-1} \mathrm{~cm}^{-1}$. The compound exhibited a broad fluorescence spectrum with a wavelength maximum at $451 \mathrm{~nm}$ upon excitation at $330 \mathrm{~nm}$. The maximum wavelength of absorption and emission and Stokes shift values of compounds $\mathbf{2 a - i}$ and $\mathbf{4}$ are shown in Table 2.

From the calculations it was seen that the compounds show appreciably large Stokes shifts suggesting considerable difference between geometries of the ground and first excited singlet states of these molecules. The absorption and fluorescence maxima did not exhibit any changes upon varying the polarity of the solvent, ruling out any solvatochromic effect in these compounds. The singlet energy, $E_{\mathrm{S}}$ of representative compound $\mathbf{2} \mathbf{b}$ was calculated from the point of intersection of absorption and normalized fluorescence spectra and the value was $73.02 \mathrm{kcal} / \mathrm{mol}(3.16 \mathrm{eV})$. The fluorescence quantum yields of $\mathbf{2 a - i}$ and $\mathbf{4}$ in acetonitrile were determined using relative method $^{25}$ employing quinine sulphate as reference (Quantum Yield 0.54). The results are summarized in Table 2. All the synthesized 3,6-dihydroxybenzene-1,2,4,5-tetracarboxylic acid tetraalkyl esters showed appreciably high quantum yield values, which may be probably due to the rigid structure of the molecules with intramolecular hydrogen bonding possibilities. Quantum yield value for $\mathbf{4}$ was slightly less than that of $\mathbf{2 a - i}$ owing to the difference in its structure. The fluorescence life-time of representative compound $\mathbf{2} \mathbf{b}$ was measured using time correlated single photon counting technique and a life-time value of 7.4 ns was obtained in acetonitrile. Decay profile is shown in the supporting information (Figure 1). 


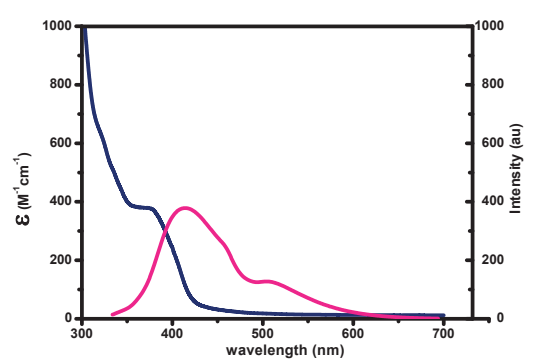

Figure 1. Absorption and fluorescence spectra of $\mathbf{2} \mathbf{b}$ in acetonitrile.

Table 2. Stokes shift and Quantum yield of 2a-i and 4

\begin{tabular}{ccccc}
\hline Compound & $\begin{array}{c}\lambda_{\mathrm{abs}} \\
(\mathrm{nm})\end{array}$ & $\begin{array}{c}\lambda_{\mathrm{em}} \\
(\mathrm{nm})\end{array}$ & $\begin{array}{c}\text { Stokes shift } \\
\left(\mathrm{cm}^{-1}\right)\end{array}$ & $\begin{array}{c}\text { Fl. Quantum yield }\left(\phi_{\mathrm{Fl}}\right) \\
(\%)\end{array}$ \\
\hline $\mathbf{2 a}$ & 375 & 459 & 4880 & 0.249 \\
$\mathbf{2 b}$ & 377 & 451 & 4498 & 0.25 \\
$\mathbf{2 c}$ & 363 & 450 & 5325 & 0.23 \\
$\mathbf{2 d}$ & 368 & 453 & 5998 & 0.234 \\
$\mathbf{2 e}$ & 366 & 453 & 5247 & 0.234 \\
$\mathbf{2 f}$ & 382 & 453 & 4103 & 0.243 \\
$\mathbf{2 g}$ & 371 & 442 & 4403 & 0.232 \\
$\mathbf{2 h}$ & 370 & 460 & 5288 & 0.231 \\
$\mathbf{2 i}$ & 390 & 480 & 4808 & 0.234 \\
$\mathbf{4}$ & 347 & 492 & 4864 & 0.204 \\
\hline
\end{tabular}

Furthermore, we have also studied the fluorescence quenching of $\mathbf{2 b}$ using dimethylamine (DMA) and picric acid (PA) (Figures 2a and 2b). Fluorescence quenching was more pronounced with PA than with DMA suggesting that the molecule $\mathbf{2} \mathbf{b}$ acts as a good electron donor in the excited state with PA as the electron accepting quencher.
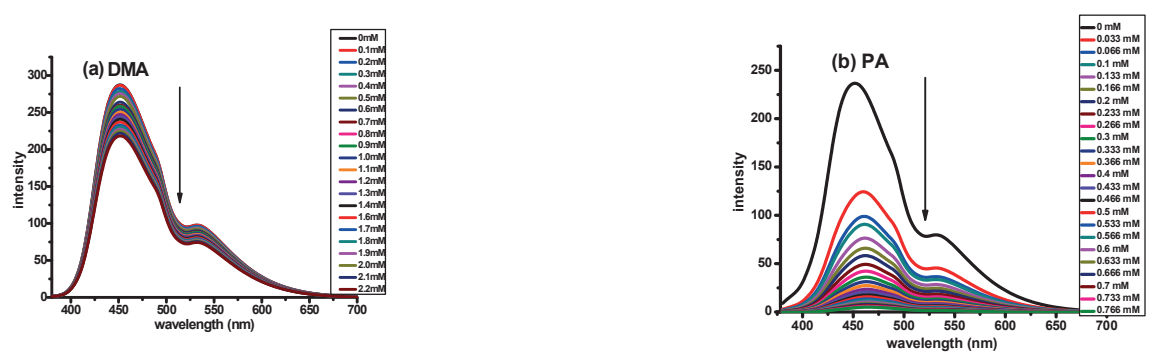

Figure 2. Steady state fluorescence spectra of $\mathbf{2 b}$ in the presence of increasing concentration of quencher a) DMA and b) PA.

Stern-Volmer plots were constructed to understand the quenching mechanism. Figures $3 \mathrm{a}$ and $3 \mathrm{~b}$ depict the Stern-Volmer plots for the fluorescence quenching of $\mathbf{2 b}$ with DMA and PA, 
respectively. A linear S-V fit is obtained for the fluorescence quenching of $\mathbf{2 b}$ with DMA. A dynamic quenching mechanism can be evoked to explain this observation. Hence it can be assumed that diffusion controlled bimolecular quenching between the quencher and the fluorophore is happening in this case. The S-V plot for the fluorescence quenching of $\mathbf{2} \mathbf{b}$ with PA shows a nonlinear upward bending relationship between $\mathrm{I}_{0} / \mathrm{I} v s$ concentration of the quencher. This non-linear behavior reveals that quenching of fluorescence of $\mathbf{2 b}$ with PA occurs through simultaneous dynamic and static mechanisms. ${ }^{26}$
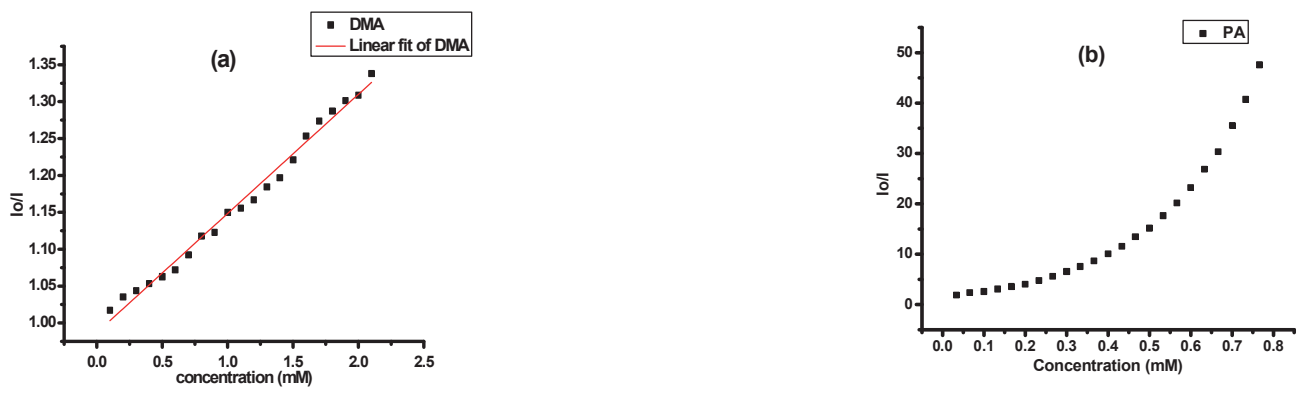

Figure 3. Stern-Volmer plots for the fluorescence quenching of $\mathbf{2 b}$ with a) DMA and b) PA.

\section{Conclusions}

A new method for the synthesis of 3,6-dihydroxybenzene-1,2,4,5-tetracarboxylic acid tetraalkyl esters has been developed. Apart from the historical importance, ${ }^{27}$ these molecules have recently been used to synthesize novel polyimides exhibiting red fluorescence with large Stokes shift values due to excited state intramolecular proton transfer phenomena. ${ }^{28}$ Compared to earlier methods for the synthesis of these molecules, the current method is milder, higher yielding and less-toxic. Further studies regarding the chemical transformations, electrochemistry and detailed photophysical properties are under way in our laboratory.

\section{Experimental Section}

General. NMR spectra were recorded on a Bruker Avance DPX-500 MHz spectrometer. Chemical shifts are reported relative to TMS as the internal standard. IR spectra were recorded on a Agilient Cary 630 FTIR spectrometer. Mass spectra were recorded under ESI/HRMS using JEOL JMS $600 \mathrm{H}$ mass spectrometer. Absorption spectra were recorded on a PerkinElmer UV/Vis Lambda 365 spectrometer. Fluorescence spectra were recorded on a JASCO FP-8300 spectrofluorometer. Time resolved fluorescence experiment was performed by using a IBH picosecond single photon counting system employing a $375 \mathrm{~nm}$ nano-LED excitation source. Cerium (IV) ammonium nitrate (CAN) was purchased from Merck Specialties Pvt. Ltd and was used as such without further purification. Commercial grade solvents were used. Analytical thin layer chromatography was 
performed on silica gel coated on aluminium sheets and was monitored using UV light of wavelength $366 \mathrm{~nm}$. Gravity column chromatography was performed using 100-200 mesh silica gel and mixtures of hexane and ethyl acetate were used for elution. Dimethyl 1,3-acetone dicarboxylate (1a), diethyl 1,3-acetone dicarboxylate and 1,5-diphenyl-pentane-1,3,5-trione (3) were commercially available and were used as such without further purification.

Synthesis of 3,6-dihydroxybenzene-1,2,4,5-tetracarboxylic acid tetraalkyl esters. To an ice cold solution of the corresponding acetone dicarboxylic acid dialkyl ester $(100 \mathrm{mg})$ in dry $\mathrm{CH}_{3} \mathrm{CN}$ $(10 \mathrm{~mL}), 30 \mathrm{~mol} \% \mathrm{CAN}$ was added. The solution was allowed to stir and the temperature was gradually raised to RT. After completion of the reaction as indicated by TLC, the solvent was rotary evaporated and the residue was extracted with dichloromethane and washed with brine $(3 \times$ $10 \mathrm{~mL}$ ). The organic extract was dried over anhydrous $\mathrm{Na}_{2} \mathrm{SO}_{4}$ and the solvent was subsequently removed. The residue was subjected to column chromatography using silica gel 100-200 mesh and hexane/EtOAc solvent system.

3,6-Dihydroxy-benzene-1,2,4,5-tetracarboxylic acid tetramethyl ester (2a). Light yellow solid; yield: $80 \mathrm{mg}$ (41\%), mp 120.5-121.5 ${ }^{\circ} \mathrm{C}$, IR (powder): 3024, 2983, 1736, 1502, 1438, 1341, 1286, $1148 \mathrm{~cm}^{-1} .{ }^{1} \mathrm{H}$ NMR $\left(500 \mathrm{MHz}, \mathrm{CDCl}_{3}\right): \delta_{\mathrm{H}} 3.95(\mathrm{~s}, 6 \mathrm{H}), 10.54(\mathrm{~s}, 1 \mathrm{H}) .{ }^{13} \mathrm{C} \mathrm{NMR}(125 \mathrm{MHz}$, $\left.\mathrm{CDCl}_{3}\right): \delta_{\mathrm{C}} 166.8,149.9,120.2,53.2$. HRMS (ESI): $\mathrm{m} / z[\mathrm{M}+\mathrm{Na}]^{+}$calcd for $\mathrm{C}_{14} \mathrm{H}_{14} \mathrm{O}_{10}: 365.0587$; found: 365.0567 .

3,6-Dihydroxybenzene-1,2,4,5-tetracarboxylic acid tetraethyl ester (2b). Light yellow solid; yield: $88 \mathrm{mg}$ (45\%), mp 121.5-122.5 ${ }^{\circ} \mathrm{C}$ (lit. ${ }^{12} \mathrm{mp} 121.5-122.5^{\circ} \mathrm{C}$ ), IR (powder): $3078,2989,1725$, 1498, 1285, $961 \mathrm{~cm}^{-1} .{ }^{1} \mathrm{H}$ NMR $\left(500 \mathrm{MHz}, \mathrm{CDCl}_{3}\right): \delta_{\mathrm{H}} 1.40(\mathrm{t}, J 14.5 \mathrm{~Hz}, 6 \mathrm{H}), 4.41$ (q, $J 21.5 \mathrm{~Hz}$, 4H), $10.65(\mathrm{~s}, 1 \mathrm{H}) .{ }^{13} \mathrm{C} \mathrm{NMR}\left(125 \mathrm{MHz}, \mathrm{CDCl}_{3}\right): \delta_{\mathrm{C}} 166.4,150.1,120.1,96.1,62.2,13.9$. HRMS (ESI): $m / z[\mathrm{M}+\mathrm{Na}]^{+}$calcd for $\mathrm{C}_{18} \mathrm{H}_{22} \mathrm{O}_{10}: 421.3613$; found: 421.3617.

3,6-Dihydroxybenzene-1,2,4,5-tetracarboxylic acid tetrapropyl ester (2c). Light yellow oil; yield: $88 \mathrm{mg}$ (45\%), IR (Thin film): 3138, 2929, 1736, 1569, 1498, 1282, 1177, $989 \mathrm{~cm}^{-1} .{ }^{1} \mathrm{H} \mathrm{NMR}$ $\left(500 \mathrm{MHz}, \mathrm{CDCl}_{3}\right): \delta_{\mathrm{H}} 1.00(\mathrm{t}, J 18.5 \mathrm{~Hz}, 6 \mathrm{H}), 1.72-1.81(\mathrm{sex}, 4 \mathrm{H}), 4.30$ (t, $\left.J 17 \mathrm{~Hz}, 4 \mathrm{H}\right), 10.66$ (s, 1H). ${ }^{13} \mathrm{C}$ NMR $\left(125 \mathrm{MHz}, \mathrm{CDCl}_{3}\right): \delta_{\mathrm{C}} 166.7,150.1,120.2,68.1,21.7,10.3$. HRMS (ESI): $\mathrm{m} / z$ $[\mathrm{M}+\mathrm{Na}]^{+}$calcd for $\mathrm{C}_{22} \mathrm{H}_{30} \mathrm{O}_{10}: 477.4676$; found: 477.4671 .

3,6-Dihydroxybenzene-1,2,4,5-tetracarboxylic acid tetrabutyl ester (2d). Light yellow oil; yield: $92 \mathrm{mg}$ (47\%), IR (Thin film): 3176, 2961, 2857, 1732, 1460, 1248, 1161, $1080 \mathrm{~cm}^{-1} .{ }^{1} \mathrm{H}$ NMR (500 MHz, CDCl 3 ): $\delta_{\mathrm{H}} 1.10-1.18(\mathrm{~m}, 6 \mathrm{H}), 1.20-1.39(\mathrm{~m}, 4 \mathrm{H}), 1.51-1.66(\mathrm{~m}, 4 \mathrm{H}), 4.08(\mathrm{t}, J$ $16.5 \mathrm{~Hz}, 4 \mathrm{H}), 10.58(\mathrm{~s}, 1 \mathrm{H}) .{ }^{13} \mathrm{C} \mathrm{NMR}\left(125 \mathrm{MHz}, \mathrm{CDCl}_{3}\right): \delta_{\mathrm{C}} 168.0,157.0,134.0,66.0,28.3,21.6$, 13.0. HRMS (ESI): $m / z[\mathrm{M}+\mathrm{Na}]^{+}$calcd for $\mathrm{C}_{26} \mathrm{H}_{38} \mathrm{O}_{10}: 533.5739$; found: 533.5737 .

3,6-Dihydroxybenzene-1,2,4,5-tetracarboxylic acid tetrapentyl ester (2e). Light yellow oil; yield: $85 \mathrm{mg}$ (43\%), IR (Thin film): 3110, 2954, 1739, 1460, 1378, 1188, 1084, $894 \mathrm{~cm}^{-1} .{ }^{1} \mathrm{H} \mathrm{NMR}$ (500 MHz, $\left.\mathrm{CDCl}_{3}\right): \delta_{\mathrm{H}} 1.3-1.01(\mathrm{~m}, 6 \mathrm{H}), 1.82-1.60(\mathrm{~m}, 8 \mathrm{H}), 2.25-2.20(\mathrm{~m}, 4 \mathrm{H}), 4.0-4.12(\mathrm{~m}, 4 \mathrm{H})$, 10.57 (s, $1 \mathrm{H}) .{ }^{13} \mathrm{C} \mathrm{NMR}\left(125 \mathrm{MHz}, \mathrm{CDCl}_{3}\right): \delta_{\mathrm{C}} 165.6,149.1,127.9,127.4,65.4,28.6,28.5,21.6$, 13.0. HRMS (ESI): $m / z$ [M+Na] $]^{+}$calcd for $\mathrm{C}_{30} \mathrm{H}_{46} \mathrm{O}_{10}$ : 589.6802; found: 589.6810 . 
3,6-Dihydroxybenzene-1,2,4,5-tetracarboxylic acid tetra(iso-propyl) ester (2f). Light yellow oil; yield: $94 \mathrm{mg}$ (48\%), IR (Thin film): 3183, 2922, 2851, 1736, 1461, 1189, 1099, $797 \mathrm{~cm}^{-1} .{ }^{1} \mathrm{H}$ NMR (500 MHz, $\left.\mathrm{CDCl}_{3}\right): \delta_{\mathrm{H}} 1.18-1.35(\mathrm{~m}, 12 \mathrm{H}), 5.16-5.22(\mathrm{~m}, 2 \mathrm{H}), 10.58(\mathrm{~s}, 1 \mathrm{H}) .{ }^{13} \mathrm{C}$ NMR $(125$ $\mathrm{MHz}, \mathrm{CDCl}_{3}$ ): $\delta_{\mathrm{C}} 165.1,149.1,127.8,69.6,20.5$. HRMS (ESI): $\mathrm{m} / z[\mathrm{M}+\mathrm{Na}]^{+}$calcd for $\mathrm{C}_{22} \mathrm{H}_{30} \mathrm{O}_{10}$ : 477.4676; found: 477.4667 .

3,6-Dihydroxybenzene-1,2,4,5-tetracarboxylic acid tetra(tert-butyl) ester (2g). Light yellow oil; yield: $92 \mathrm{mg}$ (47\%), IR (Thin film): 3095, 2922, 2855, 1740, 1461, 1371, 1254, $1148 \mathrm{~cm}^{-1} .{ }^{1} \mathrm{H}$ NMR $\left(500 \mathrm{MHz}, \mathrm{CDCl}_{3}\right): \delta_{\mathrm{H}} 1.40(\mathrm{~s}, 18 \mathrm{H}), 9.87(\mathrm{~s}, 1 \mathrm{H}) .{ }^{13} \mathrm{C} \mathrm{NMR}\left(125 \mathrm{MHz}, \mathrm{CDCl}_{3}\right): \delta_{\mathrm{C}} 170.6$, 150.9, 123.0, 83.6, 28.6. HRMS (ESI): $m / z[\mathrm{M}+\mathrm{Na}]^{+}$calcd for $\mathrm{C}_{26} \mathrm{H}_{38} \mathrm{O}_{10}$ : 533.5739; found: 533.5743 .

3,6-Dihydroxybenzene-1,2,4,5-tetracarboxylic acid tetracyclohexyl ester (2h). Light yellow oil; yield: $89 \mathrm{mg}$ (45\%), IR (Thin film): 3040, 2937, 2858, 1733, 1453, 1259, $1120 \mathrm{~cm}^{-1} .{ }^{1} \mathrm{H}$ NMR $\left(500 \mathrm{MHz}, \mathrm{CDCl}_{3}\right): \delta_{\mathrm{H}} 1.20$ (uneven triplet, $\left.12 \mathrm{H}\right), 2.21-2.28(\mathrm{~m}, 8 \mathrm{H}), 4.08(\mathrm{q}, J 22.5 \mathrm{~Hz}, 2 \mathrm{H})$, $10.58(\mathrm{~s}, 1 \mathrm{H}) .{ }^{13} \mathrm{C} \mathrm{NMR}\left(125 \mathrm{MHz}, \mathrm{CDCl}_{3}\right): \delta_{\mathrm{C}} 179.3,162.6,126.1,70.5,31.1,29.7,28.6,22.4$ HRMS (ESI): $m / z$ [M-Na] $]^{+}$calcd for $\mathrm{C}_{34} \mathrm{H}_{46} \mathrm{O}_{10}$ : 591.7230; found: 591.7245 .

3,6-Dihydroxybenzene-1,2,4,5-tetracarboxylic acid tetrabenzyl ester (2i). Light yellow oil; yield: $85 \mathrm{mg}$ (43\%), IR (Thin film): 3136, 2948, 1736, 1628, 1498, 1390, 1267, $1174 \mathrm{~cm}^{-1} .{ }^{1} \mathrm{H}$ NMR (500 MHz, $\left.\mathrm{CDCl}_{3}\right): \delta_{\mathrm{H}} 5.12-5.19(\mathrm{~m}, 4 \mathrm{H}), 7.17-7.29(\mathrm{~m}, 10 \mathrm{H}), 10.51(\mathrm{~s}, 1 \mathrm{H}) .{ }^{13} \mathrm{C} \mathrm{NMR}(125$ $\left.\mathrm{MHz}, \mathrm{CDCl}_{3}\right): \delta_{\mathrm{C}} 172.1,153.4,142.4,133.8,130.2,129.3,128.4,65.5$. HRMS (ESI): $\mathrm{m} / z$ [M$\left.\mathrm{C}_{7} \mathrm{H}_{7}\right]$ calcd for $\mathrm{C}_{38} \mathrm{H}_{30} \mathrm{O}_{10}$ : 555.6388; found: 555.6380 .

3,6-Dihydroxy-1,2,4,5-tetrabenzoylbenzene (4). To an ice cold solution of 1,5-diphenylpentane-1,3,5-trione (3) (100 mg, $0.3759 \mathrm{mmol})$ in dry $\mathrm{CH}_{3} \mathrm{CN}$ solvent $(10 \mathrm{~mL}), 30 \mathrm{~mol} \% \mathrm{CAN}$ (61.82 $\mathrm{mg}, 0.1127 \mathrm{mmol}$ ) was added. The solution was allowed to stir and the temperature was gradually raised to RT. After completion of the reaction as indicated by TLC, the solvent was rotary evaporated and the crude residue was extracted with dichloromethane and washed with brine $(3 \times 10 \mathrm{~mL})$. The organic extract was dried over anhydrous $\mathrm{Na}_{2} \mathrm{SO}_{4}$ and the solvent was subsequently removed. The residue was subjected to column chromatography using silica gel 100200 mesh and hexane-EtOAc as solvent system. Elution with ethyl acetate/hexane (2:8), afforded the product 4 as a yellow solid; yield: $83 \mathrm{mg}$ (42\%), mp 201-203 ${ }^{\circ} \mathrm{C}$, IR (powder): 3071, 2840, $1684,1584,1423,1289,1181,931 \mathrm{~cm}^{-1} .{ }^{1} \mathrm{H} \mathrm{NMR}\left(500 \mathrm{MHz}, \mathrm{CDCl}_{3}\right): \delta_{\mathrm{H}} 7.18-8.06\left(\mathrm{~m}, 10 \mathrm{H}_{\text {arom }}\right)$, $10.08(\mathrm{~s}, 1 \mathrm{H}, \mathrm{OH}) .{ }^{13} \mathrm{C} \mathrm{NMR}\left(125 \mathrm{MHz}, \mathrm{CDCl}_{3}\right): \delta_{\mathrm{C}} 194.7,148.9,136.8,132.7,129.1,128.2$, 127.6, 127.4, 126.8; HRMS (ESI): $m / z$ [M-C $\left.\mathrm{C}_{7} \mathrm{H}_{7}\right]$ calcd for $\mathrm{C}_{34} \mathrm{H}_{22} \mathrm{O}_{6}$ : 549.5349; found: 549.5345 .

\section{Acknowledgements}

The authors thank SERB, Govt. of India for financial assistance (SB/S1/OC-43/2013). ALB thank UGC for Junior Research Fellowship. All authors thank SAIF, Cochin for NMR analysis and NIIST, Trivandrum for Mass analysis. ALB gratefully acknowledges Ms. Saumya Krishnan for 
her help in handling the spectrofluorimeter. The authors thank Dr Yoosaf K, Scientist, NIIST for his help in recording the fluorescence life-time.

\section{References}

1. Yegorov, A. S.; Ivanov, V. S.; Wozniak, A. L. Biosci., Biotechnol. Res. Asia 2014, 11, 1765. http://dx.doi.org/10.13005/bbra/1583

2. Wilson, D.; Stenzenberger, H. D.; Hergenrother, P. M. in Polyimides, Springer Science \& Business Media, 2013 and references cited therein.

3. Kittel, P. Adv. Cryog. Eng. 1998, 43. 1366.

4. Zhou, H. C.; Long, J. R.; Yaghi, O. M. Chem. Rev. 2012, 112, 673.

http://dx.doi.org/10.1021/cr300014x

5. All articles in Chem. Rev. 2012, 112, 673-1268.

6. Ai, M.; Suzuki, S. Bull. Chem. Soc. Jpn. 1974, 47, 3074. http://dx.doi.org/10.1246/bcsj.47.3074

7. Masayoshi, I.; Hideshi, H.; Kozo, T. J. Catal. 1974, 35, 225. http://dx.doi.org/10.1016/0021-9517(74)90201-2

8. Tanabe, K.; Sumiyoshi, T.; Shibata, K.; Kiyoura, T.; Kitagawa, J. Bull. Chem. Soc. Jpn. 1974, 47, 1064.

http://dx.doi.org/10.1246/bcsj.47.1064

9. Hirai, K.; Misonoo, T.; Abe, Y. J. P. US Patent 6, 127, 942, 1994.

10. Hu, Y. L.; Lu, M.; Liu, X. B.; Zhang, S. B.; Ji, Z. H.; Lu, T. T. ARKIVOC 2010, (ix), 63. http://dx.doi.org/10.3998/ark.5550190.0011.907

11. von Pechmann, H.; Wolmann, L. Ber. Dtsch. Chem. Ges. 1897, 30, 2569. http://dx.doi.org/10.1002/cber.18970300335

12. Hammond, P. R. J. Chem. Soc. (C), 1971, 1521. http://dx.doi.org/10.1039/j39710001521

13. Barbafina, A.; Elisei, F.; Latterini, L.; Milano, F.; Agostiano, A.; Trotta, M. Photochem. Photobiol. Sci. 2008, 7, 973 and references cited therein. http://dx.doi.org/10.1039/b805897k

14. Lakowicz, J. R. in Principles of Fluorescence Spectroscopy, 3rd edition.; Springer, US, 2006. http://dx.doi.org/10.1007/978-0-387-46312-4

15. Nair, V.; Deepthi, A. Chem. Rev. 2007, 107, 1862. http://dx.doi.org/10.1021/cr068408n

16. Sridharan, V.; Menendez, J. C. Chem. Rev. 2010, 110, 3805. http://dx.doi.org/10.1021/cr100004p

17. Svëtlík, J.; Veizerovă, L.; Kettmann, V. Tetrahedron Lett. 2008, 49, 3520. http://dx.doi.org/10.1016/j.tetlet.2008.03.136 
18. Žugelj, M.; Albreht, A.; Uršič, U.; Svete, J.; Stanovnik, B. ARKIVOC 2009, (vi), 137. http://dx.doi.org/10.3998/ark.5550190.0010.614

19. Pirnat, K.; Šimunek, P.; Uršič, U.; Bezenšek, J.; Grošelj, U.; Golobič, A.; Meden, A.; Svete, J.; Stanovnik, B. ARKIVOC 2011, (vi), 120.

http://dx.doi.org/10.3998/ark.5550190.0012.610

20. Prezent, M. A.; Dorokhov, V. A. Russ. Chem. Bull., Int. Ed. 2005, 54, 1343.

21. Hayashi, Y.; Toyoshima, M.; Gotoh, H.; Ishikawa, H. Org. Lett. 2009, 11, 45. http://dx.doi.org/10.1021/o1802330h

22. Smeilus, T.; Hennig, L.; Beyer, L.; Sieler, J.; Giannis, A. Synthesis 2015, 47, 1887. http://dx.doi.org/10.1055/s-0034-1380495

23. Sivan, A.; Deepthi, A. Tetrahedron Lett. 2014, 55, 1890. http://dx.doi.org/10.1016/j.tetlet.2014.01.145

24. Neises, B.; Steglich, W. Org. Synth. 1985, 63, 183. http://dx.doi.org/10.15227/orgsyn.063.0183

25. Barber, J. Chem. Soc. Rev. 2009, 38, 185.

26. Campbell, K.; Zappas, A.; Bunz, U.; Thio, Y. S.; Bucknall, D. G.; J. Photochem. Photobiol. A: Chem. 2012, 249, 41. http://dx.doi.org/10.1016/j.jphotochem.2012.08.015

27. von Nef, J. U. Justus Liebigs Ann. Chem. 1890, 258, 261. http://dx.doi.org/10.1002/jlac.18902580302

28. Kanosue, K.; Shimosaka, T.; Wakita, J.; Ando, S. Macromolecules 2015, 48, 1777. http://dx.doi.org/10.1021/ma502456f 